\title{
When hydrosociality encounters sediments: transformed lives and livelihoods in the lower basin of the Ganges River
}

\author{
Lafaye de Micheaux, Flore \\ Mukherjee, Jenia \\ Kull, Christian A.
}

\begin{abstract}
:
The hydrosocial cycle is a central analytical framework in political ecological approaches to water. It helps foreground multiple and subtle interactions between water and society, culture and politics. However, to date it has dealt little with matters other than water flows. In river contexts, biotic and abiotic components play critical roles in the way people engage with and make a living out of rivers, beyond water. This article aims to advance the hydrosocial framework with a deeper consideration of the materiality of rivers. To initiate this approach, the focus is here on sediments. Lives and livelihoods connected to river sediments remain both officially and academically under-explored. This certainly applies to the context of the Lower Ganges basin whose active channels transport huge loads of sediments mainly originating from the Himalayan slopes. Building upon an environmental history perspective and drawing on three spatially nested cases in West Bengal, India, the paper analyses instances of water-sedimentsociety interactions. The general case study presents colonial state interventions in the Lower Ganges basin waterscapes. The second case study zooms the focus on the 2-km long Farakka Barrage. These explorations reveal how an 'imported' conceptual landwater divide infused those interventions that led to unforeseen effects on riverine lives and livelihoods. Focusing on Hamidpur char, situated few kilometres upstream of the barrage, the third case study recounts the contemporary efforts of local communities to obtain revision of administrative decisions unable to deal with 'muddyscapes'. Finally, the paper engages with recent debates on the concept of hybridity in land-water nexus to reflect on the specific meaning and role of sediments.
\end{abstract}

Key words: political ecology, river basin, sediment, hydrosocial cycle, environmental history.

This is an authors' pre-print version of this paper. The final version of record is published by in the journal Environment and Planning E: Nature and Space and is available here: journals.sagepub.com/doi/10.1177/2514848618813768 or via the DOI permalink: http://doi.org/10.1177/2514848618813768

The citation of the paper is:

Lafaye de Micheaux, F, J Mukherjee \& CA Kull (2018) When hydrosociality encounters sediments: Transformed lives and livelihoods in the lower basin of the Ganges River. Environment and Planning E: Nature and Space 1 (4) : 641-663. DOI: $10.1177 / 2514848618813768$. 


\section{Highlights:}

- Hydrosocial research tends to focus on water flows.

- In river contexts, one must also engage with other material elements like sediments.

- Reflecting on sediments leads to questioning categories like land, water and hybridity.

- Hegemonic conceptual divides exist between water and land, ignoring sediments.

- Cases from the Lower Ganges basin show impact of such divides on waterscapes and livelihoods.

\section{Introduction}

A large corpus of physical geography studies shows how sediments play a key role in fluvial geomorphology, river ecology and erosion or flood hazards. Despite a considerable growth in the study of sediment transport in rivers from the 1950s, in many cases, river management still focuses on flow regime at the expense of sediment regime (Wohl et al., 2015). Similarly, lives and livelihoods connected to sediments remain often both officially and academically under-explored. However, in geography and anthropology literatures, theoretical and empirical explorations of lives in shifting land(water)scapes like meandering rivers (Abizaid, 2005; Coomes and al., 2009), temporary river islands (Cortesi and Camargo, forthcoming; Lahiri-Dutt and Samanta, 2013; Lahiri-Dutt, 2014) or in deltas (Krause, 2017; Sultana, 2010) increasingly document the role of sediments in the forms and dynamics of river-society interactions.

This article aims to advance the understanding of socio-natural processes around rivers with a renewed perspective on the materiality of rivers, notably in incorporating sediments. To do so, we mobilize the political ecology of water, and particularly the hydrosocial framework that we enrich with insights from critical physical geography. The hydrosocial cycle as defined by Jamie Linton and Jessica Budds, 'is a socio-natural process by which water and society make and remake each other, over space and time' $(2014,175)$. Hydrosocial analyses aim to reveal intertwined 'flows of water and power relations' (Budds et al., 2014), while studying material and discursive dimensions of water. In a related vein also linked to political ecology, the critical physical geography approach engages centrally with biophysical processes while calling for the greater attention to power relations (Lave and al., 2014).

We chose to explore this approach in the context of the Lower Ganges basin, in the West Bengal State of India. The Lower Ganges basin is an interesting case for pushing hydrosocial theory as it combines extreme features: situated within the GangaBrahmaputra Delta, the product of two of the world's most silted rivers and their distributaries, it is also one of the most densely populated deltas. Highly altered by terrestrial and riverine infrastructure including railway lines, roads, embankments, ports or barrages, the terrain is crisscrossed by intense human activities dependant on rivers. It is also increasingly vulnerable to climate change. The Lower Ganges basin is shaped by cyclones, coastal storms, river-induced floods, erosion and accretion phenomena, but also, indirectly, by ways of thinking about the river. The large dams and high embankments that were developed in the country since India's independence were 
the result, as geographer Kuntala Lahiri-Dutt puts it, of "objectification of rivers, depriving them of their right to spread over space [...]. The sense of oneness with rivers and attachment to them was replaced with the sense that a river, like a wild horse, needs to be 'harnessed', 'tamed' and 'controlled'" (2000, 2399). Ruling paradigms, economic expectations and power relations around water, from close to far distances (notably in the case of the British Empire), shaped Lower Ganges basin's rivers and waterscapes that in turn shaped people's livelihoods, rulers' decisions, institutional configurations and even political movements or ideas. Thus, this part of the Indian Bengal basin, through its history and up to its contemporary dynamics, fully embodies the concept of hydrosocial cycle.

In the particular context of chars (the silt islands, sandy shoals or bars that frequently emerge and disappear within the riverine channels of the basin), human engagements with sediments are critical. As shown by Lahiri-Dutt and Samanta (2013), though fragile, unstable, and at risk of disappearance, these places remain attractive possibilities to some, generally marginal, human communities, as they are fertile. Choruas (inhabitants of chars) put all their efforts in making a living from these stratified silt/sandy lands that often turn into muddy waters in monsoon seasons or get entirely submerged in one flood. These chars, which evolve not as landscapes or waterscapes, but as composite muddyscapes, exemplify instances of water-sediment-society dynamic relations.

The paper consists of five sections. Following this introduction, section 2 discusses the existing literature and justifies the relevance of proposing to enrich hydrosocial analyses in river contexts with a focus on sediments. Section 3 introduces the Lower Ganges basin and two cases where water, sediments and society interact and intermingle. The Lower Ganges basin case and the zoomed focus on the construction of the Farakka Barrage reveal how colonial and post-colonial state interventions dramatically altered the natural deposition pattern of its alluvial sediments and disrupted Choruas' livelihoods as well as socio-political equations. With a greater zoom in Malda district, upstream of the Farakka barrage, the third case recounts the contemporary efforts of Choruas' communities to obtain the revision of administrative decisions unable to deal with 'muddyscapes' (Hamidpur char). In section 4, further analytical insights are drawn from the incorporation of sediments into the hydrosocial framework. The discussion also engages with recent debates on the concept of hybridity in the land-water nexus. Section 5 wraps up the argument, raising possibilities for further lines of inquiry.

\section{Engaging hydrosocial literature with rivers' sediments}

\subsection{Hydrosocial literature and river's materiality}

Our approach positions itself within the 'political ecology of water', a critical literature that studies the social and political dimensions of water (Loftus, 2009). This literature mainly criticizes apolitical analyses of water-related phenomena. Case studies related to drought for example show how power relations affect access to water as well as scientific knowledge produced about water, while water scarcity gets 'naturalized' in discourses (Budds, 2009; Kaika, 2003; Mehta, 2011). In this vein, the concept of hydrosocial cycle emerged within the field to emphasize the internal and dialectical relation between water and society, drawing attention to 'how water is made known and represented, and its effects' (Linton \& Budds, 2014, 177). Such analysis may for example 
reveal the political processes behind the scientifically-produced 'Minimum Flow Requirements' of the Garonne River in south-western France and their effects on water control decisions (Fernandez, 2014).

Conversely, the role of the materiality of water is also acknowledged in this framework. "We contend that the hydrosocial cycle comprises a process of co-constitution as well as material circulation" (Linton and Budds, 2014, 170). In Linton and Budds' terms, water materiality is characterized by its 'agential role' in hydrosocial relations $(2014,176)$. For example, hydrologic processes produce material flows of water but may also be agents of social, economic or cultural reorganizations (like after a severe flood); other studies also showed the agential properties of assemblages of water and technology/infrastructure (Barnes, 2012; Birkenholtz, 2009; Swyngedouw, 2007). Political ecology of water, and within it, hydrosocial analysis, have been applied to study rivers and river basins (Alatout, 2012; Bakker, 1999; Norman and Bakker, 2009; Matthews, 2012; Molle, 2005; Peterson, 2000; Sneddon and Fox, 2006; Vogel, 2012 and for hydrosociality, Bakker, 2000; Boelens, 2014; Bouleau, 2014; Bourblanc and Blanchon, 2014; Budds, 2009; Budds and Hinojosa, 2012; Fernandez, 2014, Hommes et al., 2016; Mollinga, 2014; Perreault, 2013; Swyngedouw, 2007). However, to date, we observed that in river contexts, hydrosocial studies often restrict considerations of the materiality of rivers to water flows. For instance, the sediments that rivers carry, or the biodiversity they shelter, are often not considered or only briefly taken into account. The perspectives of dominant actors and available data often promote a view of river waters as a liquid resource only. Lack of available data on river ecosystems may be a constraint for researchers. For example, in their hydrosocial study in Peru, Budds and Hinojosa (2012) mentioned that the impacts of mining extraction on the ecology of headwaters are scarcely documented. Mollinga's (2014) study of an irrigation canal in south India also corroborates this argument as he showed that singularising the meaning of river water in productive terms was the result of a state strategy.

Some scholars however mobilize more than water flows in their analyses. Bouleau (2014) highlights the mutual shaping of scientific categories used to describe hydrosystems, like bioindicators such as diatoms or habitats such as wetlands, and the waterscapes themselves; Perreault (2013) shows the significance of distinguishing different 'forms of nature', like sediment and water, and different qualities, like clean or contaminated, to reveal instances of local communities' dispossession in a mining region of the Bolivian Andes. This attention to materiality is also stressed by Birkenholtz (2016) in his study of water transfers from rural to urban areas in Rajasthan, showing that water's variability, spatially and temporally, affects hydrosocial relations as well as capital accumulation.

Drawing on these works and on critical physical geography that calls for integration of physical and human geographies while acknowledging the politics of environmental science (Lave, 2015), we seek to enrich hydrosocial analyses with greater attention to materiality of rivers 'over space and time'. In this regard, we choose to focus here on the sediment component of rivers. 


\subsection{Looking at sediments}

Sediment regimes are crucial to aquatic and riparian ecosystems (see Wohl et al., 2015). Unintended ecological effects occur if sediment supply and transport are overlooked in river management (Poff et al., 2006). These findings from physical geography, sedimentology, fluvial geomorphology, hydrobiology or biochemistry on hydrosystems, confirm the importance of sediment circulation in river systems.

Building on these works, we propose to more fully incorporate sediment in hydrosocial analysis, drawing on a body of recent, critical literature that emerged in anthropology and geography dedicated to muddy terrains, or those places where sediments, rivers, and societies intersect (Lahiri-Dutt, 2014; Krause, 2017a; Cortesi and Carmago, forthcoming). We notably mobilize useful concepts and insights from Franz Krause and Kuntala Lahiri-Dutt for our approach.

Krause (2017a) proposes an 'amphibious anthropology' to adequately account for lives in deltas. This approach encompasses concepts of wetness (recognizing the spectrum of realities between dry and wet, and their local importance), volatility (instability and fluidity of humans and non-humans' interactions) and rhythms (analysis of clashing and/or corresponding ecological and social interrelated rhythms). These latter two concepts rightly reflect the high variabilities of sediment regimes; moreover, "rivers respond to changes in water and sediment inputs at varying temporal and spatial scales, but such scales can be substantially different for sediment and water" (Wohl et al., 2015, 359). Thus incorporating sediments leads to a greater attention to temporalities and rhythms (Krause, 2017b).

Lahiri-Dutt's work has been a major inspiration for the present article. Lahiri-Dutt strongly argues for the need to "[reconsider] one of the foundational binaries [of geography], that of land and water" $(2014,1)$. Engaging with the concept of hybridity beyond mere material forms (or a simple mix of water and land), she reworks the 'wet theory' conceived by anthropologists like Appadurai and Breckenridge (2009). One of her aims is to bring "more fluidity in speaking of hybrid environments" (Lahiri-Dutt, $2014,2)$, noting that most of geographical metaphors are related to land only. As an instance of not excluding complexities or ambiguities, she further invites critical geographers "not to give up mud and silt in favour of either land or water" in their explorations of hybridity (Lahiri-Dutt, 2014, 8), drawing empirical insights from the Bengal context. In section 4, we therefore engage with recent debates on hybridity to further reflect on the meaning, place and role of sediment in human geography.

\subsection{Incorporating sediments in the hydrosocial cycle}

In order to better guide our empirical investigation, our proposition is to revisit the model of the hydrosocial cycle proposed by Linton and Budds (2014), with its three components: $1 . \mathrm{H}_{2} 0$, standing for water's materiality; 2 . social power/structure and 3 . technology/infrastructure. In this conceptualization, other aspects like discourses, ideas, representations of $\mathrm{H}_{2} \mathrm{O}$ or knowledge are internalized in what the authors call 'water', at the centre of the cycle (see Figure 1). 
In our proposition of a materially-enriched hydrosocial cycle, we instead articulate four components. Referring here to the dialectical approach that infuses the concept (Harvey, 1996; Linton and Budds, 2014), we understand these components as intimately connected processes, sustaining, undermining, shaping or disrupting each other into new configurations, though belonging to different levels of abstraction and to different space-time dimensions (including the distinction between experienced or external spatialities and temporalities). The four components we propose are: 1. Meanings and interpretations (including knowledge, scientific and/or local) of land and water ('muddyscapes'); 2. Land and water-related governance and power relations; 3. Resource (here water and sediment) use and exchange patterns; 4. Physical and biological processes, partly mediated or affected by technology. The seemingly prominence of social processes (3 out of 4 ) over physical processes do not refer to a quantified representation of the relative importance of those processes. The idea here is rather to make the possibilities of interactions among varied social dimensions and physicalities more visible. Figure 1 aims to illustrate these components with a limited choice of key words.

As in Linton and Budds' conceptualisation, each component exerts actions and eventually brings changes to other components affecting the whole cycle. As a consequence, the cyclical process does not follow a regular path among components; the idea of a cycle is however kept as all components of the cycle finally become affected along a historical trajectory, as shown in the empirical section that follows.

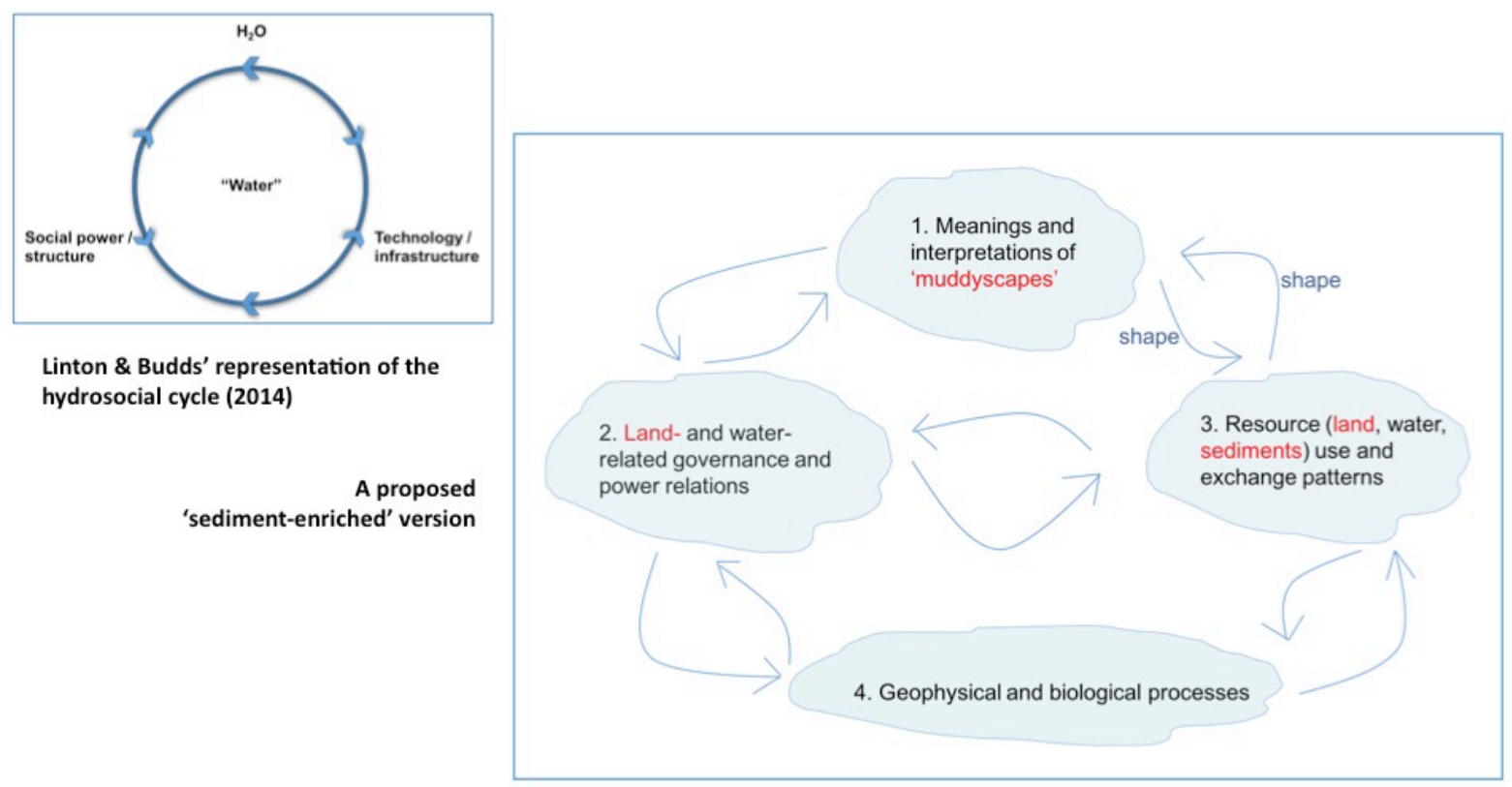

Figure 1: A 'sediment-enriched' hydrosocial cycle

Our aim is now to illustrate why sediments matter in river-society dynamics. The next section presents three cases in West Bengal, India. Our case studies are nested in temporal and spatial scale from large to small: the general environmental history of the 
Lower Ganges basin, the Farakka barrage construction event and its consequences, and Hamidpur char that is located about 11 kilometres upstream of Farakka barrage.

In each of these cases, we shed light on mutual interactions and shaping processes among the four (proposed) components of the hydrosocial cycle (see Figure 1). We particularly study the role of conceptual frames of thought (i.e. component 1) and how Choruas, as well as authorities, adjust and react to such 'moving terrains' (components 2 and 3). We incorporate physical processes (component 4) through qualitative descriptions, rather than through quantitative research on sedimentation and erosion, for such work in the Ganges basin lacks sufficient data (see notably Wasson, 2003; Singh, 2015). In this way, we depart from a true socio-sedimentological case of the kind that critical physical geography would call for. Through our cases, we focus instead on how the land/water divide worldview has affected people's living conditions in the Lower Ganges basin until now.

\section{The Lower Ganges basin: transformed lives and livelihoods}

\subsection{Introducing the lower basin of the Ganges River}

... a riverine plain that is part land, part water, but is neither in its entirety... from the breadth of the delta mouth to the microcosmic worlds of silt islands or chars that lie within the riverbeds Kuntala Lahiri-Dutt $(2014,4)$

Shared by India and Bangladesh, the vast alluvial plain of the lower basin of the Ganges River is characterized by an intricate network of interlacing channels and abandoned meanders, as well as marshes and occasional higher lateritic tracts. The GangesBrahmaputra delta is a tide-dominated delta with highly turbid estuarine channels. Deposition processes characterise the delta, as the river slope is only about $4 \mathrm{~cm} / \mathrm{km}$ (Singh et al., 2007). The active Ganges channel upstream of the delta is highly sinuous, making large meander loops within a $20-30 \mathrm{~km}$ wide valley (Singh IB, 2008). Two hydrological phenomena dominate. First, there is huge seasonal variation in flow discharges due to the monsoon regime: monsoon flows (July-September) reach 10 to 100 times non-monsoon flows (Singh et al., 2007). Second, the river transports a considerable amount of sediments to the delta area (600 to 1200 million tons/year bedload, Wasson 2003), mainly from upper Himalayan highly erodible slopes (Wasson, 2003). Singh et al. (2007) note that about half of the sediment discharge to the world's oceans originates from the rivers of South-East Asia due to the morphodynamic evolution of the Himayalan range. Monsoon flows thus carry about $90 \%$ of the annual sediment load into the delta region (Singh IB, 2008). As a consequence, in monsoon period, "bankfull discharges result in an enormous spontaneous transportation of sediments to the Bay of Bengal along with changes in the river channel morphology" (Singh et al., 2007, 157). The Ganges riverine system therefore remains dynamic, with bank erosion, accretion, and changing courses of rivers (Rudra, 2014).

Our empirical focus is on the Indian part of this geographical unit, within the state of West Bengal. The river Ganges enters the West Bengal State in the Malda district, with the Rajmahal Hills on the right side. After some $35 \mathrm{~km}$, at Farakka, the Ganges 
bifurcates ${ }^{1}$ into two major branches, the Padma River (in a south-east direction, towards Bangladesh) and the Bhagirathi River (to the south, towards the city of Kolkata). In the centuries leading up to the Farakka Barrage, the Ganga-Padma River was the main branch. The slowly decaying Bhagirathi River used to birfucate about $40 \mathrm{~km}$ downstream, near Mithipur, Murshidabad district. However, the commissioning of the Farakka Barrage in 1975 on the Ganges, a diversion structure designed to increase the flow in the Bhagirathi River, put an end to the natural degeneration of that channel. The Bhagirathi River is now constituted of a $39-\mathrm{km}$ long feeder canal that is derived from upstream of the barrage, and joins the sea about $300 \mathrm{~km}$ downstream. In its tidal stretch, notably in Kolkata, the river is named Hugli River. The river finally merges with the Indian Ocean near Sagar Island, on the western side of the Sundarbans, a complex of coastal islands. Dynamic phenomena of coastal erosion, accretion and submersion continuously shape and reshape these deltaic islands or tidal bars (see Figure 2).

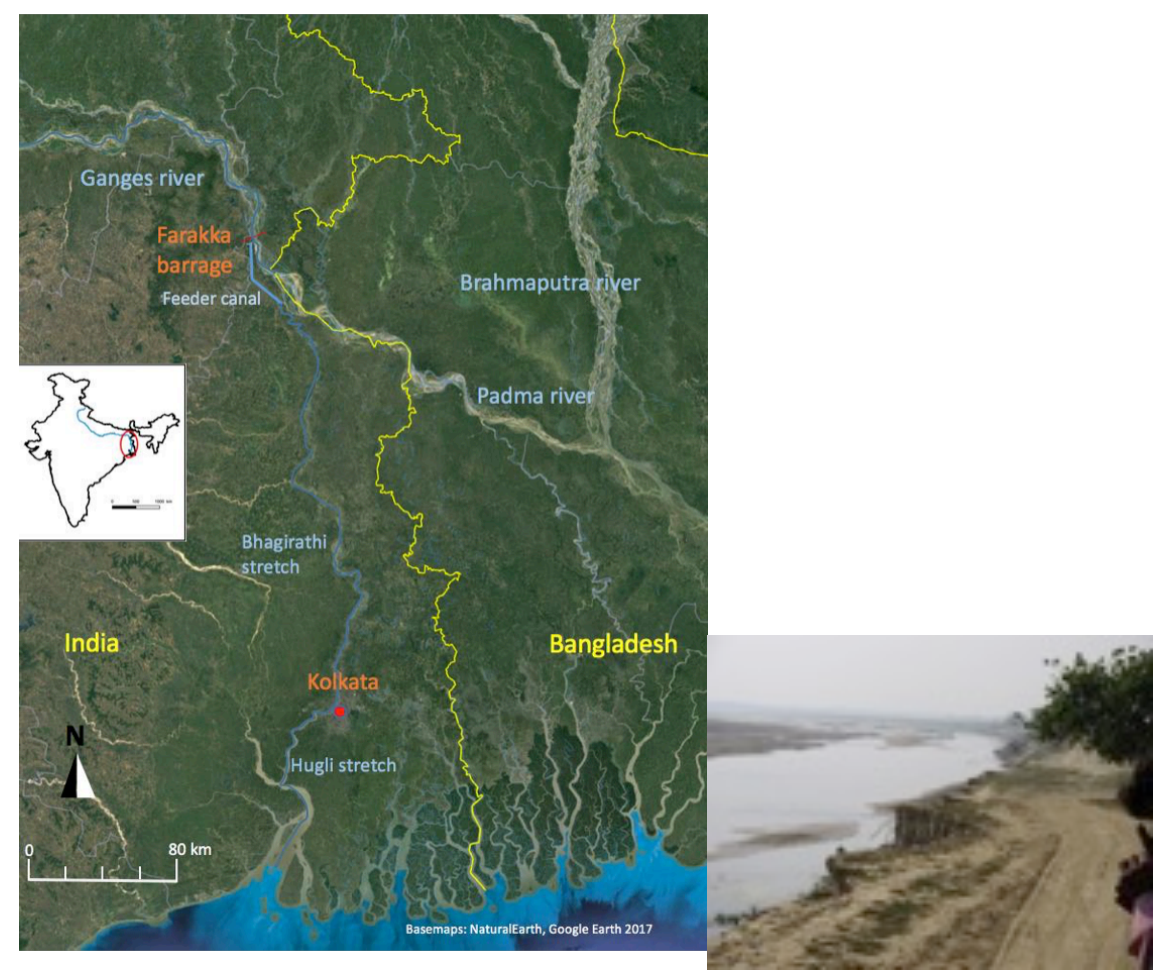

Figure 2: Schematic map of the Lower Ganges basin

Figure 3: Nirmal char in Murshidabad district, West Bengal (India)

The dynamicity and the changing courses of the Bengal basin's rivers also lead to the creation of channel bars or "sandy islands". Locally termed as chars, these silted/sandy bars frequently emerge or disappear among riverine channels, as the sediment is deposited then gradually moved downstream. The distinction between suspended load and bedload is difficult to make in the Lower Ganges basin: Ganges river sediments show a strong overlap of grain size between bed load and suspended load deposits (Singh IB, 2008). Both bed and suspended load consist of mainly fine to very fine sand; the suspended load also includes a high proportion of silt and clay. In particular, very

1 The description simplifies the situation, as the whole system is more complex with temporary disconnected or reconnected distributaries or channels, according to intensities of dry and monsoon seasons and sedimentation/erosion processes. 
fine sand and silt-clay fraction constitutes the sediment of the Bhagirathi (Singh IB, 2008). Nearly $80 \%$ of bedload is transported as 'graded suspension' due to bottom turbulence during monsoon flows (Singh et al., 2007). A large amount of suspended load, rich in silt, is transported, then deposited on chars: "several centimetres thick muddy sediment is found deposited on top of channel bars after each flood, essentially representing the suspended load" (Singh IB, 2008, 354). The chars are made of deposited sand and silt strata, and, as a consequence, they are highly vulnerable to fluvial erosion processes (see Figure 3).

Though temporary, and at risk of floods and erosion, many of these chars are inhabited by Choruas who farm and reside there. Richer in silt than coastal chars (where this term is also used), the riverine chars are fertile. They are rendered attractive by the difficulties of accessing agricultural land, as in India overall ${ }^{2}$. The entire delta is highly populated (in West Bengal only, there are about 57.2 million inhabitants in the 9

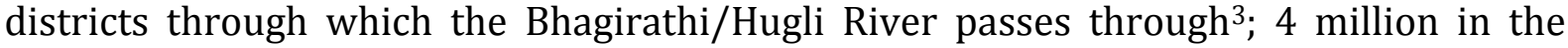
Malda district alone) with human density average at district level in so-called rural areas up to 1700 people/sq. km (Hoara district, Census India, 2011).

The next section studies water-sediment-human dynamic relations in the Lower Ganges basin. Inspired by the Indian environmental, and more specifically water history literature (Mukherjee 2018), this retrospective situates the Farakka Barrage project within two generic "moments » in the history of the Lower Ganges basin: the colonial and the post-colonial periods.

3.2. Why sediments matter, case 1: From land/water divide to increased erosion in colonial era

This section narrates shifting configurations of the hydrosocial cycle, in relation to the disruptions introduced by colonial rulers on water-sediment-society dynamics. At the end of each paragraph, we briefly note which of the cycle components presented in Figure 1 are involved. As shown below, these material and discursive practices were largely infused by a modernist paradigm that conceptualized land and water as strictly separate entities (the land/water divide) and that restricted rivers to productive water channels (D’Souza 2009).

In the seventeenth century, just before the establishment and consolidation of the East India Company in Bengal, the dominant physical features of the basin were similar to modern ones: monsoon-type climate, silt-rich lands suitable for rice and other cultures and geomorphic dynamicity of rivers and channels (Bernier, 1689). Overflow irrigation was widely practised (Klingensmith, 2007). In this system, the nutrient-rich, silt-laden monsoon floodwaters were distributed, watering and more importantly fertilizing fields, spreading fish over the countryside and sweeping away mosquitoes (Klingensmith, 2007). Floodwaters were directed through a system of wide, shallow canals (khals) with minimal embankments (bunds); during the monsoons, breaches were made to these canals to allow flooding (Willcocks, 1930). As an outcome, in the seventeenth century,

\footnotetext{
${ }^{2}$ India counted more than 144 millions of landless farmers in 2011, near 55\% of agriculture-engaged workers (source: Census India, 2011, http://www.censusindia.gov.in, consulted September 5, 2017)

3Malda (4.0), Murshidabad (7.1), Nadia (5.2), Burdwan (7.7), Hooghly (5.5), Kolkata (4.5), Howarh (4.9) and 24 Parganas North (10.0) and South (8.2) districts. Kolkata metropolitan region counts about 14 million inhabitants. Figures from Census India, 2011.
} 
the French traveller François Bernier praised the prosperity of the region, stating that Bengal is richer than Egypt, producing abundant surpluses in rice and sugar and attracting foreign traders from many parts of the world for its crops, spices, silk clothes and other goods (Bernier, 1981).

The colonial era introduced major changes to existing river-society relations. The latter were characterized by rapports d'accommodation, or "relations of adjustment" (Reclus, 1889, our translation) or "dancing with the mood of the River" (Lahiri-Dutt and Samanta 2007). The British rulers carried with them the classical modern western paradigm that considered the environment as a mere externality (Berque, 2014) that should be tapped, in contrast to the pre-modern viewpoint of reciprocal nature-society relations (Sarkar, 2010). For instance, Colonel Cotton proclaimed in Report on the Mahanuddy, "all deltas require essentially the same treatment" (Cotton, 1858, 3). This is an example of components 1 and 3 (see Figure 1) mutually shaping each other (below, in the interest of brevity, we simply note, for instance [Comp $1><\operatorname{Comp} 3]$, at the end of the paragraph).

Moreover, the colonizers introduced a land/water divide (D'Souza 2009; Lahiri-Dutt, 2014; Bhattacharya, 2018) or a sharp conceptual separation between river water and its sediments. In the modernist European tradition, notably since early seventeenth century, land-water hybrids like swamps, silt islands, and sandbanks were considered treacherous, leading to innumerable drainage, reclamation and embankment campaigns (Cosgrove, 1990; Morera, 2011). This mental framework was applied to colonial territories where modern hydraulic techniques (using pumps, dredging devices, locks and sluices) were used to transform precarious waterscapes into durable landscapes (see for example Bhattacharya, 2018). While 'land exorcised of water' is transformed into property, fostering revenue generation and management, flowing waters were valorised in engineering visions to generate resource output (D'Souza, 2006, 3). Rivers were seen as liquid flows and represented in financial units. For instance administrator Trevelyan mentions in On Godavari Irrigation and Navigation,about monsoon flows: '4,20,000 cubic yards of water/hr flowed into the sea at the rate of Rs. $500 / \mathrm{hr}$ i.e., 12,000/day for 240 days and it gave Rs. 2,880,000' (Rao, 2011, 149). [Comp $1><$ Comp 3]

The British colonizers transformed the ruling paradigm towards a "rule for profit", subordinating the region to colonial capitalist relations and to British administrative and financial needs. With their smooth liquid surfaces, waterways were designated to serve as the cheapest and quickest means of transportation (Reynard, 2005). As in Orissa's Mahanadi delta, watercourses 'calibrated as arteries for trade, however, principally serve as technical arrangements to circulate the economy of land' (D'Souza, 2009, 4). In accordance with this 'colonial hydrology' (D'Souza, 2006), loaded with 'imperial science' (Gilmartin, 1994) and 'technochauvinism', rivers were channelized, shortened, dredged, embanked and straightened; numerous meanders, bends, loops, braids, adjoining wetlands, marshes, swamps and other forms of water-soil admixtures were eliminated (D'Souza, 2009). Newly excavated canals were constructed ${ }^{4}$, with high banks that impeded easy overflow of water as well as silt deposition. [Comp $2><$ Comp 4]

Many socio-economic consequences unfolded. An embankment regime was established. While the maintenance of overflow irrigation had previously been paid out of the

${ }^{4}$ At the same period, the emblematic Upper Ganga Canal system was excavated for irrigating the Doab region (Uttar Pradesh) 
general land tax and was available to all cultivators free of additional charge, the new arrangements expected peasants to pay for water use and for embankment works. The age-old overflow irrigation practiced in the Lower Ganges basin was replaced by perennial irrigation (Mishra, 1997; Mishra, 2008; D'Souza, 2002; D'Souza, 2006; Singh P, 2008; Singh, 2011). From community-managed small-scale structures, the overall irrigation system became centrally designed and engineered by scientists and technocrats under the aegis of the Irrigation Department (Gilmartin, 1994; Weil, 2006), with a clear neglect of sediments' roles and benefits. Authorities perceived floods as an obstacle restraining routine and regular revenue collection, especially after the Permanent Settlement in eastern India (Allen et al., 2017). A flood (water/silt) dependent agrarian regime transformed into a flood vulnerable landscape (D'Souza, 2002). [Comp $3><$ Comp 2]

With the continuous extension of fixed embankments (dikes created by railway lines, road networks and further for flood protection itself), the flood situation only worsened with time; some places got regularly "trapped into water" for long period of time, affecting lives and livelihoods of the inhabitants (Mishra, 2008). On the other hand, the British rulers started to consider chars as land or assets as shown in the introduction of the Bengal Alluvion and Diluvion Act (BADA) act of 1825. In this act, the key factor to establishing land rights in the court of law was for instance the payment of rent, even on diluviated land. Massive survey operations were also initiated to produce cadastral maps for revenue survey lists (or khatians). [Comp $4><$ Comp 2]

3.3. Why sediments matter, case 2: The Farakka Barrage or a new cycle of disruption

This section focuses on the Farakka Barrage project that created a major disruption of the hydrosocial relations in Bengal with far-reaching consequences spatially (up to Bangladesh) and temporally (up to today). For our analysis, we however focus on riverrelated sedimentation and erosion issues in India.

Conceived during the colonial times, but implemented by Indian authorities in the postindependence period, the Farakka Barrage initiated a new cycle of disruption within the Lower Ganges basin. This huge infrastructure, among the longest barrages in the world (2.6 km long), was initially designed to address the recurrent and massive siltation of the Kolkata Port and to improve the navigability of the Hugli River. Sediments were perceived as a problem and 'clear water' as the solution to generate revenue through riverine trade and transportation. Between 1853 and 1946, British experts periodically reiterated the idea of a barrage on the Ganges near Jangipur with a feeder canal to bring water surplus to the Bhagirathi river (MEA Report, 1978; Mukherjee, 2011). It is interesting to note here that the Boundary Commission under the Chairmanship of Cyril Radcliffe also considered the immense importance of the Farakka Barrage and hence deviated from the principle that contiguous Muslim majority areas should form Pakistan. Murshidabad (with a Muslim majority), where Farakka is situated hence remained in India and in exchange a non-Muslim majority district of Khulna went to the former East Pakistan (MEA Report, 1978). Re-appropriated by the Indian authorities, the Farakka Barrage Project then began in 1962 and was completed in 1971. Between 1971 and 1975, the $39 \mathrm{~km}$-long feeder canal was excavated and the project was finally commissioned in May 1975, becoming a national emblem of Indian technocracy and sovereignty. [Comp $2><$ Comp 3] 
However, the outcome of the project related to sedimentation processes was largely illplanned. Notably, induced discharge from the barrage has not been able to reduce sedimentation at the Kolkata Port; the annual quantum of dredging in the shipping channels of the Kolkata and Haldia Ports' area has actually increased during the postFarakka period (Rudra, 2003). The barrage has disrupted not only downstream water flow but also river sediment movements in diverse ways. The barrage has been contested by Bangladeshi authorities due to the contentious sharing of Ganges water between India and Bangladesh ${ }^{5}$; it has also been challenged within India by activists, politicians and local residents (press or website reports ${ }^{6}$ and field interviews). These actors notably denounce the amplitude of sedimentation changes and their consequences in the two channels (Ganges/Padma and Bhagirathi rivers), upstream and downstream. In addition, because the barrage gates are never fully open (in order to stabilize the expected upstream pond water level, even during most of monsoon season), sediment deposition has increased, resulting in the formation of several shoals upstream of the barrage. These shoals have led to increased meandering and sinuosity of the river as well as lateral flow instability (Mazumder, 2017; Thakur et al., 2012). The ecology of the main channels, upstream and downstream, has also been transformed due to flow velocity reduction and abiotic changes (temperature and turbidity); these changes have contributed to modifications of fish diversity and abundance, notably the reduction of a high-value commercial species (Hilsa fish) population (IITs, 2012, 11-12) as well as the decrease of the emblematic Ganges dolphin (Sinha 2000; Sinha and Kannan 2014). [Comp $2><$ Comp 4]

Since sedimentation has increased upstream, the riverbed has been raised, intensifying lateral erosion of sandy banks (Thakur et al., 2012). As the upstream right bank is of hard rock at the Rajmahal hills area, deep erosion mainly occurs on the left bank. As a result, for instance, in Malda district, the river channel was displaced to the left by $7 \mathrm{~km}$ between 1923 and 1999 (Mazumder, 2017) and more than $1 \mathrm{~km}$ between 2003 and 2005 within the Kaliachak-II block, erasing some villages (Thakur et al., 2012). Repeated floods have weakened soil structure of the banks. On many occasions, marginal embankments or spurs have been breached, causing higher flood damages. In the 1995 and 1998 floods, 450 people died and properties worth about 10 billion INR were damaged (Mazumder, 2017). In Murshidabad district, downstream of the barrage, erosion patterns were disrupted leading to destruction of 'mature' chars, already inhabited and cultivated (Rudra, 2003). Due to the increased emergence, submergence, re-emergence and re-submergence of chars, Choruas suffer from what has been called a 'SDRR' (settlement>displacement>re-settlement>re-displacement) syndrome, with some people being forced to move more than four times, and even up to 16 times within a time span of 15 years with a relative indifference from authorities (Mukherjee, 2011a). [Comp $4><$ Comp 3]

\subsection{Why sediments matter, case 3: Hamidpur char, West Bengal}

\footnotetext{
5 Though a water sharing treaty has been signed in 1997 and water data, however not available for the general public, is now shared among an Indo-Bangladeshi commission (Sen, 2017, personal communication).

${ }^{6}$ See for example SANDRP report https://sandrp.wordpress.com/2014/11/25/lessons-from-farakka-as-we-plan-more-barrages-onganga/(accessed September 21, 2017), Times of India article, July 16, 2016 http://timesofindia.indiatimes.com/city/patna/BiharCM-demands-removal-of-Farakka-barrage-on-river-Ganga/articleshow/53244938.cms (accessed September 21, 2017).
} 
The case of Hamidpur char in Malda district briefly captures some reactions and political initiatives of local Choruas towards these moving 'muddyscapes'. Our aim here is to narrate a story where water-sediment-society relations and processes not only generate uncertainty and fragility, but also zones of possibilities.

We visited this char and its inhabitants several times in 2010 for a study on livelihoods and ecosystem services, then again in July 2017 for the purpose of this research. We also visited other chars in the Murshidabad district. We travelled in pre-monsoon period, where one has to walk kilometres (no vehicle apart from tractors may drive on the thick sand layer) on sandy land, sometimes cultivated with underground water use or sometimes bare; we also travelled in monsoon or post-monsoon periods, when only small boats or ferries allow one to reach destinations and when green and dense fields of jute or rice demonstrate the fertility of the plain's soils (see Figures 4 and 5).

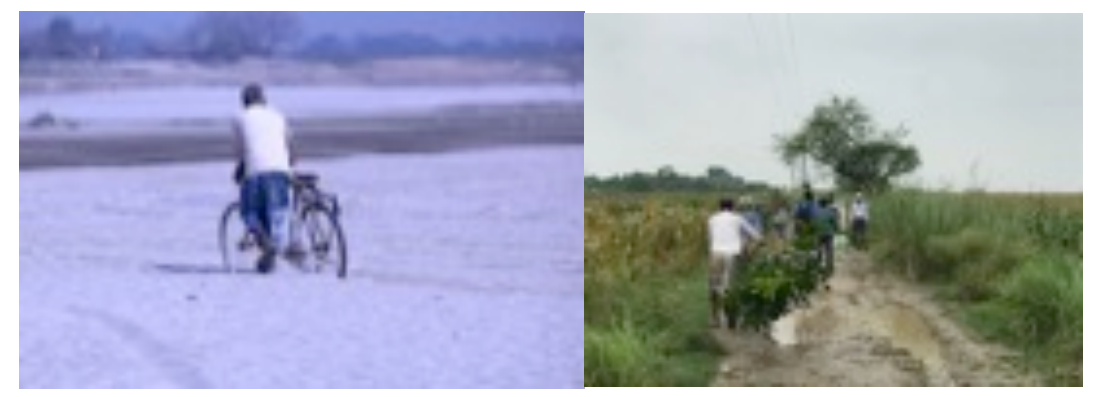

Figure 4: Pre-monsoon 'muddyscape', Nirmal char, Murshidabad district, West Bengal (courtesy: Koushik Chowdhury)

Figure 5: Monsoon 'muddyscape', Hamidpur char, Malda district, West Bengal

We interviewed local administrators at district and local levels (district magistrate, block development officer and staff, state delegate to Gram Panchayat, i.e. the local council of the "village"). We consulted relevant local documentation in administrative offices (reports and maps). To complement these sources of information, we had on-site discussions with Choruas engaged in public activities (member of Gram Panchayat, local coordinator of the West Bengal State's Nirmal Bangla programme, representative of the Gram Panchayat to the Block Disaster Management team) or in daily activities (women, elderly, farmers, etc.). 


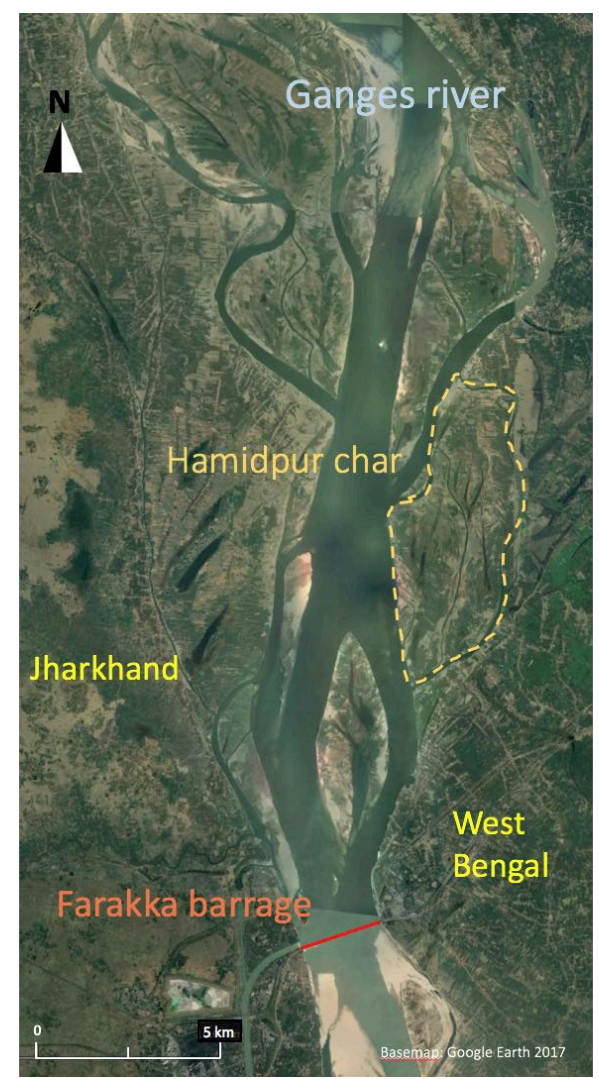

Figure 6: Location map of Hamidpur char, Malda district, West Bengal

In order to illustrate the dialectical co-production of river, sediment and society, and instead of labelling each paragraph as in the previous section, the main features of the hydrosocial cycle in this story, here shifting assemblages of representations and meanings of land and water, technology, materiality of river, uses, institutional arrangements and power equations, are first summed up in the box below with ten main points.

Box 1: Hamidpur char case, Malda district, West Bengal

1. The post-colonial ruling paradigm, inherited from British representations such as the land/water divide and the preeminence of Kolkata port economics, led Indian national authorities to assert their capability and power through the construction of the Farakka Barrage on the main channel of the River Ganges.

2. The barrage modified water flows, but affected deposition and erosion patterns within the riverbed as well as lateral embankments' strength.

3 . In the context of embankment and irrigation regimes inherited from colonial times, these changes led to increased flood and lateral erosion, with submergence of some mature chars and creation of some new chars. This caused displacement and migration of Choruas as well as deleterious impacts on people's livelihoods (the SDDR syndrome or settlement>displacement>re-settlement>re-displacement, see Mukherjee, 2011).

5. In response, authorities could not/did not want to deal with these uncategorized 'muddyscapes', neither fixed land nor water, subject to seasonal changes.

6. People were refused welfare program support as their land, and their official identity attached to it, were lost while the new chars retained the status of water-logged nonrevenue land, thus "administratively orphans". 
7. In reaction, grassroots movements emerged in the Malda district to build a political force to push for recognition of Choruas' rights and fight administrative decisions.

8. The discourse of the Choruas got strengthened by scientific arguments developed by scholar-activists like Kalyan Rudra about the impact of Farakka Barrage on the sediment regime.

9. These movements finally became successful in Hamidpur char with the delivery of identity cards, voter cards and ration cards, later with the construction of schools, flood shelters and better roads.

10. Though the char land remains categorized as shikasti (i.e. non-revenue land, whose literal meaning is 'defeated'), there is now an effective integration of Hamidpur Choruas in local institutions like Gram Panchayat, flood commission or Nirmal Bangla (state) programmes.

We now move to the detailed account of this narrative. Hamidpur char belongs to Kaliachak II development block, Malda district (see Figure 6). This block, situated $15 \mathrm{~km}$ upstream of Farakka Barrage, covers 15,700 ha and a population of about 210,000 . The majority of the population are farmers. Among the 15 blocks of the Malda district, Kaliachak II is one of the most vulnerable to floods and river bank erosion. Over 20 years, about a fourth of the block territory has been eroded: 22 villages were completely destroyed and eight others partially swallowed by the River (Kaliachak II BDO, 2007). Besides erosion, floods regularly destroyed crops and housings: within Hamidpur Gram Panchayatboundary, eight villages remained waterlogged in 2011, 2013, 2015 and 2016 (Kaliachak II BDO, 2017).

In Hamidpur, people who were affected by land erosion due to the progressive eastward shifting of the Ganges (with massive erosion in 1971 according to local residents) had to migrate to nearby available lands. Thus, they settled in newly emerged chars that had appeared on the other bank of the River, in the neighbouring state of Jharkhand. There, they renamed the place Hamidpur to retain the connection with their initial land. However, they were denied any property rights as those areas are considered as shikasti or governmental non-revenue land according to the Revenue bill?. As in other chars of West Bengal, Bihar or Jharkhand, the lives of newly settled Choruas remained precarious as migrations caused an oversupply of agricultural labour force, stressing wages to low levels. Moreover, migration, trade and land conflicts, lack of public utilities as roads, communications, hospitals and maternal health facilities were other significant constrains in the chars (Mukherjee 2011a; Dutta, 2011, Lahiri-Dutt and Samanta, 2013). There were also instances of illegal trafficking and other criminal activities as these areas easily remained out of authorities' sight. In the official perspective, these places were emblems of uncertainty and vulnerability and hence unsuitable for any governmental investment (Mukherjee 2011a) and rehabilitation issues were not considered (Rudra 2003). Government social and health schemes were not implemented, as people were not registered as proper citizens (Mukherjee 2011).

In 1986, a severe flood in Jharkhand drove more than half of the population of that local 'Hamidpur char' to move back to West Bengal. People from three to four mouzas (groups of villages) however remained in Jharkhand. The newcomers settled on a large and new char (about $7 \mathrm{~km}$ long and $4 \mathrm{~km}$ wide) that re-emerged next to the left bank of the Ganges river, separated from the western mainland by a new small river channel. That

${ }^{7}$ Once submerged by a river channel, a re-emerged land remains governmental property and no revenue can be collected from it. 
area lied approximately at the same spot of mainland Hamidpur's previously submerged areas (interview of Hamidpur GP' executive assistant, July 2017). However, the Choruas experienced repeated erosion and floods, notably during 1995, 1998, and 2002. Moreover, being denied rights by West Bengal authorities, they had no identity cards, neither voter cards nor ration cards that allow Below-Poverty-Line (BPL) populations to access rice and other basic commodities at low prices.

In 1998 troubled by the loss of their houses and livelihoods, and against the negligible role of the government, a small group of villagers from nearby Panchanandapur created the Ganga Bhangan Pratirodh Action Nagorik Committee (GBPANC). This grassroots movement received the support of action groups and NGOs such as Child Rights and You. These organizations initially aimed at better rehabilitation and relief for the Choruas. They then surveyed and mapped the chars, in order to initiate the institutionalization of these lands. They also promoted activism towards recognition and assertion of citizenship rights of Choruas. Scholar-activists like geographer Kalyan Rudra from Kolkata supported their cause by disseminating studies on Farakka Barrage's responsibility in sediment regime disruptions and its impact on char erosion in Malda and Murshidabad districts (Rudra, 2003).

Finally, in December 2010, GBPANC managed to organize a meeting at the Hamidpur char itself, in the presence of the Additional District Magistrate of Malda district. Inhabitants were told to bring and show to the administrator their past property entitlements. As a direct consequence of this event, in 2011, Choruas got identity cards and voter cards. Two primary schools and a junior school were constructed between 2012 and 2015, allowing children from the char to join schools. The char got access to electricity in 2015, a tangible sign of marginalization reduction. Since 2014, a woman from the char has been elected as Member of the Hamidpur Gram Panchayat. Since char residents were recognized officially, this paved the way for political participation (for instance within the local flood commission, or with Nirmal Bangla (Clean Bengalschemes, etc.), disaster planning, and delivery of government services (construction of emergency shelters, health programs, etc.).

Between 2005 and 2011, people thought that only classification of chars as payasti (i.e. revenue land) could lead to access to government schemes and provide official identities to Choruas. However, the char remains shikasti land or non-revenue land; no taxes are then collected on agriculture revenues. As a consequence, thanks to the high fertility of the char soil and according to the head of the Kaliachak II block, "people are not poor there" (field interview, July 2017).

This particular case of a successful grassroots movement shows the potentials and possibilities of moving terrain where flood or erosion may come anytime. In this case, official recognition of the residents' existence and needs has been crucial. However, as the head of Kaliachak II Block explains, Hamidpur char is particular in the sense that some easy identifiable land was available for the settlers thanks to re-emergence of land. In contrast, in areas of the Jharkhand-West Bengal border, many chars remain like 'orphans': as of now, no decision has been taken to attribute these chars to one of the two states. Vulnerabilities of Choruas there remain unabated. In 2018, GBPANC was still an active association that defined its mission as promoting a 'complete awareness' about river erosion and the associated problems (GBPANC's website, accessed September 
2018). Its aim remained to put pressure on government for conducting technical assessments, understanding empirical realities and crafting policies for welfare of erosion-victims in general and Choruas in particular.

\section{What do we miss when we miss sediments? Rethinking hybridity}

These Lower Ganges basin cases reveal how sediments transported by rivers are embedded in river-society interactions. We have shown the magnitude of Farakka Barrage's disruption of sedimentation processes in the Lower Ganges basin; and the effect of the submergence/re-emergence of chars on Hamidpur Choruas' political mobilization to fight against administrative decisions. As observed in these cases, as well as in projects like the Inter-Linking River project promoted by the current Indian government (the general aim of this project is to transfer water from water-rich river basins to water-scarce basins), river sediments are often absent from discourses and ideologies. When deposited or when in suspension, they are often misinterpreted as being only land or only water. They are however involved, along with water, in effective dynamic relations with society, shaping and being shaped by it.

Anthropologist Krause (2017b) argued recently that this land-water nexus does matter, socially and culturally, engaging with a debate around this nexus and the concept of hybridity. He suggests that a geographer's vision like Lahiri-Dutt's (2014) gives too much attention to the spatial aspect of the land-water nexus. According to Krause, it is not so much of a (spatial) hybrid but instead a lived and experienced temporality, "a set of spatio-temporal rhythms of increasing and decreasing wetness and fluidity" that is significant (Krause, 2017b, 1). He illustrates his approach with two ethnographic cases from Northern Europe and shows how the experience of people engaging with their 'inbetween environments' (wetland, floodplain) is closely intertwined with 'inherent rhythmicity' of temporalities like seasonal floods or hydropower-oriented manipulations on water level.

Krause's approach points to 'rhythmicity', "rather than to historicity and futurity" $(2017 \mathrm{~b}, 5)$. In our interpretation, this approach pays less attention to long-term perspectives and political dimensions. In the Lower Ganges basin, these dimensions cannot be overlooked. We showed how the colonial legacy in land/waterscapes and in the land/water conceptual divide still very much infused contemporary dynamics. In such "post-colonial" landscapes, one should use political and even ontological lenses to address them, as the hydrosocial framework rightly suggests. It is the way we understand the call from Lahiri-Dutt to rethink land as "aqueous, fluid, spongeous and uncertain" $(2014,3)$. Beyond referring to outcomes of rhythmic physical processes like tides, floods or seasons, these terms are metaphors. They oppose colonial/hegemonic perspectives that consider lands as "terra firma" and that reify a land-water divide.

Krause also engages with the concept of (land-water) hybridity: according to him, this concept often carries implicit spatial focus (it describes a particular environment) and rather reinforces the conceptual divide between land and water (it is thought as a mixture of both, thus "[positing] them as building blocks of the world")(2017b, 2). Krause notably cites Swyngedouw's writings in 2006, where the author takes some distance with the concept of hybridity he initially contributed to develop in political ecology of water: "the notions of 'hybridity' or 'cyborg' are misleading if not radically 
reproducing the underlying binary representation of the world" (Swyngedouw, 2006, 113). However, Lahiri-Dutt expressly defines hybridity not as the mixture of two environments, but as the expression of flux, uncertainty and the tension between presence and absence: "sometimes a given environment, sometimes another, sometimes both and sometimes neither" $(2014,18)$. In that debate, looking at sediments may open new conceptual directions. Sediments are neither water, nor land, they are mineral grains. Depending on the time, on magnitude of flows, on topography, on grain size and on many other subtle factors, they may be subsumed in one or the other. Water, even with suspended sediments, remains aqueous. Sediments may thus be a metaphor of the illusory fixity of categories of land and water, and even hybridity itself, as a third "thing". They also bring plurality (the absolute number of grains and their complex chemistry and size distribution), offering in that sense many more possibilities than a singular hybridity. They finally represent what remains to be known (the complexity of physical phenomena determining one mineral grain's trajectory), resisting the attempts to master representation of reality, while - in contrast to hybridity- being in the same time a resource directly in contact with the humans engaged with their environment.

Turning back to the hydrosocial framework, thinking on the roles and meanings of sediments confirms the relevance of paying better attention to materiality over space and time in this approach (Birkenholtz, 2016). It also confirms the significance of the question 'what is water and how is it made known?' that Linton and Budds point to (2014, see also Linton, 2010; Bouleau, 2014). Finally, it complements and confirms the dialectical thinking adopted in the hydrosocial cycle concept that emphasizes processes and relations instead of fixed things and categories (Harvey, 1996; Linton and Budds, 2014).

\section{Conclusion}

In this paper, we showed how sediments transported by rivers are intricately interwoven into river-society interactions. The Lower Ganges basin case testifies that sediments are sites of social/physical interactions. Until now, while scientific studies and modelling address some empirical dimensions, these socio-natural realities are not much considered by Indian official authorities. For instance, the draft sediment management policy posted by the Ministry of Water Resources, River Development and Ganga Rejuvenation gives little attention to social issues: no socio-economic assessment is mentioned alongside the scientific studies, mathematical model studies or physical model studies (MoWR, 2017). The draft seems to approve activities like sand and boulder mining, construction of storage reservoirs and riverbank protection/antierosion in floodplains, under the condition of respecting sustainable management guidelines edited in 2016. But potentially deleterious impacts on human occupation of downstream or upstream floodplains are not mentioned in the 2016 guidelines for sustainable sand and gravel mining, edited by the Central Ministry of Environment and Forests (MoEF 2016). Human occupation in floodplains is for example qualified as 'encroachment' (MoWR 2017, 2,6-7) and not as existing occupancy that should be considered in the context of on-going changes and impacts.

The principal contribution of this paper has been to introduce and incorporate sediment within the ambit of hydrosociality. The Lower Ganges basin that is partly land and partly water, and neither in its entirety, inhabited by numerous marginalized communities, 
exemplifies the significance of incorporation of sediments in water research, not only from the physical [hydrological/geomorphological] point of view, but also from socioeconomic, political and cultural aspects. Furthermore, these dynamics of river-sedimentsociety 'metabolism' extend across long-term temporal conjunctures, as we showed from environmental history.

The hydrosocial approach provides a critical alternative in considering the liminal spaces' of hybrid water/lands, reframing them as "not [only as] lines of separation but zones of interaction... transformation, transgression and possibility" (Howitt, 2001, 240). Sediment-enriched hydrosociality, entering the muddy terrain of Bengal basin, critically interrogates the modernist view of the environment, which "firmly believed in a watertight divide of water and lands, robbing the rivers of their histories and extracting them from their social contexts of human experience" (Lahiri-Dutt, 2014, 9). There is much more to rivers than just water. Here, we have only pointed to sediments. One could go further to the riverine biota, nutrients or micropollutants; all are socionatural realities begging for a broader analysis.

Bibliography:

Abizaid, C (2005) An anthropogenic meander cutoff along the Ucayali River, Peruvian Amazon. Geographical Review 95 (1):122-35.

Alatout S (2012) Hydro-imaginaries and the Political Geography of the Jordan River. In: Davis DK and Burke E (eds) Environmental imaginaries of the Middle East and North Africa. Athens, Ohio: Ohio University Press, pp.218-245.

Allen A, Hofmann P, Mukherjee J and Walnycki A (2017) Water trajectories through nonnetworked infrastructure: insights from peri-urban Dar es Salaam, Cochabamba and Kolkata. Urban Research \& Practice 10(1):22-42.

Appadurai A and Breckenridge CA (2009) Foreword. In: Mathur A and Da Cunha D (eds) Soak: Mumbai in an Estuary. New Delhi: Rupa Publications, pp.1-3.

Bakker K (1999) The politics of hydropower: developing the Mekong. Political Geography 18(2): 209-232.

Bakker K (2000) Privatizing Water, Producing Scarcity: The Yorkshire Drought of 1995. Economic Geography 76(1): 4-27.

Bernier F (1981) Voyages dans les Etats du Grand Mogol. Paris: Fayard.

Berque A (2014) La mésologie, pourquoi et pour quoi faire? Nanterre: Presses universitaires de Paris Ouest.

Bhattacharyya D (2018) Empire and ecology in the Bengal Delta: the making of Calcutta. Cambridge, United Kingdom; New York, NY: Cambridge University Press. 
Birkenholtz T (2009) Groundwater Governmentality: Hegemony and Technologies of Resistance in Rajasthan's (India) Groundwater Governance. Geographical Journal 175 (3): 208-20.

Birkenholtz T (2016) Dispossessing Irrigators: Water Grabbing, Supply-Side Growth and Farmer Resistance in India. Geoforum 69 (February): 94-105.

Blanchon D (2016) Radical Polical Ecology et Water studies. In: Chartier D and Rodary E (eds) Manifeste pour une géographie environnementale: géographie, écologie, politique. Paris: Presses de la Fondation nationale des sciences politiques, pp.255-274.

Boelens R (2014) Cultural politics and the hydrosocial cycle: Water, power and identity in the Andean highlands. Geoforum 57: 234-247.

Bouleau G (2014) The co-production of science and waterscapes: The case of the Seine and the Rhône Rivers, France. Geoforum 57: 248-257.

Bourblanc M and Blanchon D (2014) The challenges of rescaling South African water resources management: Catchment Management Agencies and interbasin transfers. Journal of Hydrology 519: 2381-2391.

Budds J (2009) Contested H20: Science, policy and politics in water resources management in Chile. Geoforum 40(3): 418-430.

Budds J and Hinojosa L (2012) Restructuring and Rescaling Water Governance in Mining Contexts: The Co-Production of Waterscapes in Peru. Water Alternatives 5(1): 119-137.

Budds J, Linton J and McDonnell R (2014) The hydrosocial cycle. Geoforum 57: 167-169.

Coomes OT, Abizaid C and Lapointe M (2009) Human modification of a large meandering Amazonian river: genesis, ecological and economic consequences of the Masisea cutoff on the central Ucayali, Peru. Ambio 38 (3):130-134.

Cosgrove D (1990) Platonism and practicality: hydrology, engineering and landscape in sixteenth century Venice. In: Cosgrove D and Petts G (eds) Water, engineering and landscape: water control and landscape transformation in the modern period. London and New York: Belhaven Press, pp.35-53.

Cotton A (1858) cited in Rao E (2011) Taming 'Liquid Gold' and Dam Technology: A Study of the Godavari Anicut. In: Kumar D, Damodaran V and D'Souza R (eds) The British Empire and the Natural World: Environmental Encounters in South Asia. Oxford and New York: Oxford University Press.

D'Souza R (2002) Colonialism, Capitalism and Nature: Debating the Origins of Mahanadi Delta's Hydraulic Crisis (1803-1928). Economic and Political Weekly 37(13): 1261-1272.

D'Souza R (2006) Drowned and Dammed: Colonial Capitalism, and Flood control in Eastern India. New Delhi: Oxford University Press. 
D'Souza R (2009) River as resource and land to own: the great hydraulic transition in Eastern India. In: Conference on Asian environments shaping the world: conceptions of nature and environmental practices, 19-21 March, 2009, National University of Singapore, Singapore.

Dutta P (2011) Migration as source of risk-aversion among the environmental refugees: The case of women displaced by erosion of the river Ganga in the Malda district of West Bengal, India. In: Research conference on Environmental Change and Migration: From Vulnerabilities to Capabilities, Bad Salzuflen, Germany, 5-9 December 2010. Bielefeld: COMCAD.

Fernandez S (2014) Much Ado About Minimum Flows... Unpacking indicators to reveal water politics. Geoforum 57: 258-271.

Gilmartin D (1994) Scientific empire and imperial science: colonialism and irrigation technology in the Indus basin. The Journal of Asian Studies 53(4): 1127-1149.

Harvey D (1996) Justice, nature and the geography of difference. Cambridge Mass. [etc.]: BBlackwell.

Hommes L, Boelens R and Maat H (2016) Contested hydrosocial territories and disputed water governance: Struggles and competing claims over the Ilisu Dam development in southeastern Turkey. Geoforum 71: 9-20.

Howitt, R. (2001). Rethinking resource management: justice, sustainability and indigenous peoples. London: Routledge.

Indian Institutes of Technology (2012) Hilsa, an assessment in Lower Ganga River Basin, India. Ganga Basin Plan Report 29, June 2012. Available

athttp://nmcg.nic.in/Grbmpreports.aspx (accessed 19 September 2017).

Kaika M (2003) Constructing Scarcity and Sensationalising Water Politics: 170 Days That Shook Athens. Antipode 35(5): 919-954.

Kaliachak II Block Development Office (2007) Brief note on land erosion. District Management section report. Kaliachak II Block Development Office, Malda district.

Kaliachak II Block Development Office (2017) Disaster Management Plan, 2017-2018. Kaliachak II Block Development Office, Malda district.

Klingensmith D (2007) One Valley and a Thousand: Dams, Nationalism, and Development. New Delhi: Oxford University Press.

Krause F (2017a) Towards an Amphibious Anthropology of Delta Life. Human Ecology 45(3): 403-408.

Krause F (2017b) Rhythms of wet and dry: Temporalising the land-water nexus. Geoforum. 
Lahiri-Dutt K (2000) Imagining Rivers. Economic and Political Weekly, 35(27): 2395$2397+2399-2400$.

Lahiri-Dutt K (2014) Beyond the water-land binary in geography: Water/lands of Bengal re-visioning hybridity. ACME: An International E-Journal for Critical Geographies, 13(3): 505-529.

Lahiri-Dutt K and Samanta G (2007) 'Like the Drifting Grains of Sand': Vulnerability, Security and Adjustment by Communities in the Char lands of the Damodar River, India. South Asia: Journal of South Asian Studies 30(2): 327-350.

Lahiri-Dutt K and Samanta G (2013) Dancing with the River: People and Life on the chars of South Asia. Yale: Yale University Press.

Lave R, Wilson MW, Barron ES, et al. (2014) Intervention: Critical physical geography: Critical physical geography. The Canadian Geographer / Le Géographe canadien 58(1): 110.

Lave R (2015) Introduction to special issue on critical physical geography. Progress in Physical Geography 39(5): 571-575.

Linton J (2010) What is water? The history of a modern abstraction. Vancouver: UBC Press.

Linton J and Budds J (2014) The hydrosocial cycle: Defining and mobilizing a relationaldialectical approach to water. Geoforum 57: 170-180.

Loftus A (2009) Rethinking Political Ecologies of Water. Third World Quarterly 30(5): 953-968.

Matthews N (2012) Water Grabbing in the Mekong Basin - An Analysis of the Winners and Losers of Thailand's Hydropower Development in Lao PDR. Water Alternatives 5(2): 392-411.

Mazumder SK (2017) Behaviour and Training of River Near Bridges and Barrages: Some Case Studies. In: Sharma N (ed) River System Analysis and Management. Singapore: Springer Singapore, pp.263-278

Ministry of Environment and Forests (2016) Sustainable sand mining management guidelines. New Delhi: Ministry of Environment and Forests.

Ministry of External Affairs (1978) The Farakka Barrage. New Delhi: Ministry of External Affairs.

Ministry of Water Resources, River Development and Ganga Rejuvenation (2017) Draft Policy on Sediment Management, July 2017. New Delhi: Ministry of Water Resources, River Development and Ganga Rejuvenation. Available at http://www.wrmin.nic.in/writereaddata/Draft_Policy_on_Sediment_MgmtJune2017.pdf (accessed on 19 September 2017). 
Mehta L (2011) The social construction of scarcity: the case of water in Western India. In: R. Peet et al. (eds) Global Political Ecology. London: Routledge: pp.371-386.

Mishra D (1997) The Bihar Flood Story. Economic and Political Weekly 32(35): 22062217

Mishra D (2008) Trapped Between the Devil and Deep Waters. Dehradoon: People's Science Institute, SANDRP.

Molle (2005) Elements for a political ecology of river basins development: The case of the Chao Phraya river basin, Thailand. International Water Management Institute.

Mollinga PP (2014) Canal irrigation and the hydrosocial cycle. Geoforum 57: 192-204.

Morera R (2011) L'assèchement des marais en France au XVIIe siècle. Collection 'Histoire', Rennes: Presses Universitaires de Rennes.

Mukherjee J (2011) The Farakka Barrage: A Review from the Indo-Bangladesh Perspective after 36 years. Proceedings of the Indian History Congress 72 (Part II): 105463.

Mukherjee J (2011a) No voice, no choice: Riverine changes and human vulnerability in the 'chars' of Malda and Murshidabad. Occasional Paper 28, 2010. Kolkata: Institute of Development Studies. Available at http://idsk.edu.in/wpcontent/uploads/2015/07/OP-28.pdf (accessed on 19 September 2017).

Mukherjee J (2018) From hydrology to hydrosociality: Historiography of waters in India. In: Caradonna J (ed) Routledge Handbook of the History of Sustainability. UK: Routledge.

Norman ES and Bakker K (2009) Transgressing Scales: Water Governance Across the Canada-U.S. Borderland. Annals of the Association of American Geographers 99(1): 99117.

Perreault T (2013) Dispossession by Accumulation? Mining, Water and the Nature of Enclosure on the Bolivian Altiplano. Antipode 45(5):1050-1069.

Peterson G (2000) Political ecology and ecological resilience: An integration of human and ecological dynamics. Ecological Economics 35(3): 323-336.

Poff NL, Olden JD, Pepin DM et al. (2006) Placing global stream flow variability in geographic and geomorphic contexts. River Research and Applications 22(2): 149-166.

Rao E (2011) Taming 'Liquid Gold' and Dam Technology: A Study of the Godavari Anicut. In: Kumar D, Damodaran V and D'Souza R (eds) The British Empire and the Natural World: Environmental Encounters in South Asia. Oxford and New York: Oxford University Press.

Reclus E (1889) Préface. In: Metchnikoff L La civilisation et les grands fleuves historiques, Paris: Hachette, p.V. 
Reynard NS (2005) Impact of climate change on flood flows in river catchments. Bristol: Environment Agency.

Rudra K (2003) The Encroaching Ganga and Social Conflicts: The Case of West Bengal, India. West Bengal: Department of Geography, Habra H.C. Mahavidyalaya. Available at http://www.gangawaterway.in/assets/02Rudra.pdf (accessed on 19 September 2017).

Rudra K (2014) Changing river courses in the western part of the Ganga-Brahmaputra delta. Geomorphology 227: 87-100.

Singh IB (2008) The Ganga River. In Gupta A (ed) Large Rivers: Geomorphology and Management. Chichester, West Sussex; Hoboken, NJ: John Wiley \& Sons.

Singh M, Singh IB and Müller G (2007) Sediment characteristics and transportation dynamics of the Ganga River. Geomorphology 86(1-2): 144-175.

Singh P (2008) The colonial state, zamindars and the politics of flood control in north Bihar (1850-1945). The Indian Economic \& Social History Review 45(2): 239-259.

Singh P (2011) Flood Control for North Bihar: An Environmental History from the 'Ground-Level' (1850-1954). In: Kumar D, Damodaran V and D'Souza R (eds) The British Empire and the Natural World: Environmental Encounters in South Asia. Oxford and New York: Oxford University Press.

Sinha RK (2000) Status of the Ganges River dolphin (Platanista gangetica) in the vicinity of Farakka Barrage, India. In: Reeves RR, Smith BD, Kasuya T (eds) Biology and conservation of freshwater cetaceans in Asia. Occasional Paper of the IUCN Species Survival Commission. Report No 23. Gland, Switzerland and Cambridge, United Kingdom: IUCN.

Sinha RK and Kannan K (2014) Ganges River Dolphin: An Overview of Biology, Ecology, and Conservation Status in India. AMBIO 43(8): 1029-1046.

Sneddon C and Fox C (2006) Rethinking transboundary waters: A critical hydropolitics of the Mekong basin. Political Geography 25(2): 181-202.

Sultana F (2010) Living in hazardous waterscapes: Gendered vulnerabilities and experiences of floods and disasters. Environmental Hazards9(1): 43-53.

Swyngedouw E (2006) Circulations and metabolisms: (Hybrid) Natures and (Cyborg) cities. Science as Culture 15(2): 105-121.

Swyngedouw E (2007) Technonatural Revolutions: The Scalar Politics of Franco's Hydro-Social Dream for Spain, 1939-1975. Transactions of the Institute of British Geographers, New Series 32(1): 9-28. 
Thakur PK, Laha C and Aggarwal SP (2012) River bank erosion hazard study of river Ganga, upstream of Farakka barrage using remote sensing and GIS. Natural Hazards 61(3): 967-987.

Vogel E (2012) Parcelling out the watershed: The recurring consequences of organising Columbia river management within a basin-based territory. Water Alternatives 5: 161190.

Wasson RJ (2003) A sediment budget for the Ganga-Brahmaputra catchment. Current Science 84(8): 1041-1047.

Weil, B. (2006). The rivers come: Colonial flood control and knowledge systems in the Indus basin, 1840s-1930s. Environment and History, 12(1) 3-29.

Willcocks, W. (1930). Lectures on the ancient system of irrigation in Bengal and its application to modern problems. Calcutta: University of Calcutta.

Wohl E, Bledsoe BP, Jacobson RB et al. (2015) The Natural Sediment Regime in Rivers: Broadening the Foundation for Ecosystem Management. BioScience 65(4): 358-371. 